Article

\title{
Assessing the Effect of Leaf Litter Diversity on the Decomposition and Associated Diversity of Fungal Assemblages
}

\author{
Jing Gao, Fengfeng Kang, Tianyu Li, Xiaoshuai Song, Weihong Zhao, Xiaowen Yu and \\ Hairong Han *
}

College of Forestry, Beijing Forestry University, QingHua East Road 35, Haidian District, P.O. Box 372, Beijing 100083, China; E-Mails:gaojingcrystal@126.com (J.G.); phoonkong@163.com (F.K.); 326312168@qq.com (T.L.); 372173820@qq.com (X.S.); 215776966@qq.com (W.Z.); 849562232@qq.com (X.Y.)

* Author to whom correspondence should be addressed; E-Mail: hrh_forest_china@126.com; Tel./Fax: +86-10-6233-6015.

Academic Editors: Rodney J. Keenan and Eric J. Jokela

Received: 31 March 2015 / Accepted: 7 July 2015 / Published: 14 July 2015

\begin{abstract}
Although the effect of litter mixture on decomposition has been well documented, few studies have examined the relationships between richness and relative abundance of leaf species in litter mixture and changes in universal fungal communities during the decomposition process in temperate forests. In this study, we used the litterbag method and included three leaf litter species, i.e., aspen (Populus davidiana Dode), birch (Betula platyphylla Sukaczev) and oak (Quercus mongolica Fischer ex Ledebour), to investigate the mass loss rate and diversity of universal fungal communities in each litter treatment, which were sampled in situ after 180, 240, 300 and 360 days of decomposition (between 2012 and 2013) in broadleaved mixed forests in Chinese temperate forests. Eight mixture proportions were examined: pure aspen litter (10A), pure birch litter (10B), pure oak litter (10O), 50\% aspen litter mixed with 50\% birch litter (5A:5B), 50\% aspen litter mixed with $50 \%$ oak (5A:5O), 50\% birch litter mixed with 50\% oak litter (5B:5O), 10\% birch litter mixed with $80 \%$ aspen litter and 10\% oak litter (1B:8A:1O), 30\% birch litter mixed with $40 \%$ aspen litter and 30\% oak litter (3B:4A:3O). Over 360 days of decomposition, approximately $46.6 \%, 43.6 \%, 28.0 \%, 54.4 \%, 40.2 \%, 39.5 \%, 54.5 \%$ and $49.46 \%$ of litter mass was lost from 10A, 10B, 10O, 5A:5B, 5A:5O, 5B:5O, 1B:8A:1O and $3 \mathrm{~B}: 4 \mathrm{~A}: 3 \mathrm{O}$, respectively. In addition, the number of fungal denaturing gradient gel electrophoresis (DGGE) bands showed a positive correlation with mass loss rate,
\end{abstract}


indicating a positive feedback between leaf litter decomposition and universal fungal communities in the leaf litter. The results revealed that the $5 \mathrm{~A}: 5 \mathrm{~B}, 1 \mathrm{~B}: 8 \mathrm{~A}: 1 \mathrm{O}$ and 3B:4A:3O litter mixtures had a synergistic effect on the litter mixture, while the 5A:5O and 5B:5O litter mixtures had a nearly neutral effect on the litter mixture. Thus, leaf litter species composition and relative abundance seem to be more important than leaf litter richness in driving the direction and magnitude of litter mixture decomposition.

Keywords: litter mixture decomposition; non-additive effects; mass loss; fungal community; PCR-DGGE

\section{Introduction}

Litter decomposition is an important ecological process that provides the main source of nutrients for microorganisms and plays a crucial role in the maintenance of soil fertility in forest ecosystems [1]. The decomposition of litter is primarily directly related to distinct substrate quality [2,3]. Moreover, environmental conditions, including soil fertility, microclimate and decomposer communities in the forest floor, can also alter decomposition rates indirectly [4]. Particularly, microorganisms are the animate component of organic matter, which play essential roles in the transformation from organic matter to inorganic matter [5].

Generally, the rate of litter decomposition is positively correlated with the initial $\mathrm{N}$ content of the litter, but negatively correlated with the initial $\mathrm{C} / \mathrm{N}$ and lignin $/ \mathrm{N}$ ratios of the litter over a wide range of ecosystems [6,7]. Specifically, the concentrations of mineral nutrients (such as $\mathrm{Mn}$ or $\mathrm{Ca}$ ) and diverse recalcitrant compounds in leaf litter are related to the rate of litter decomposition [8,9]. It has been demonstrated by current research that compared with chemical parameters of the litter, litter species would provide better explanatory power for the rate of litter decomposition $[3,10]$.

However, litter in natural ecosystems always decomposes a mixture of various leaf species. A large number of studies have shown that the litter mixture could have additive (neutral) or non-additive (synergism or antagonism) effects on litter decomposition. In contrast with non-additive effects, the additive effects can be predicted from the rates of decomposition in the monocultures of each component species [11,12]. According to Ostrofsky [13], these non-additive effects may be controlled by four principal mechanisms. In the first instance, this refers to nutrient transfer, where nutrients are translocated from high-quality to low-quality litter, either through a water film, or actively transported through the hyphae of fungi connecting two different types of litter [14]. This favors rapid colonization of decomposer communities and accelerates the decomposition of recalcitrant litter in the mixture. Second, the rate of litter decomposition could be reduced by specific secondary compounds (tannins or phenolics). Tannins inhibit microbial growth and activities by forming resistant complexes with proteins [15]. These proteins, combined with polyphenols render the $\mathrm{N}$ unavailable to the decomposition organisms and consequently slow them down [15]. The third mechanism, i.e., the structural stability of litter beds, improves microclimatic conditions, which could offer a more suitable habitat for decomposer communities, therefore facilitating litter decomposition. In contrast, however, we should point out that this mechanism protects labile soluble compounds from leaching. Finally, 
synergistic or antagonistic effects on the decomposition of various types of species in mixed litter may occur simultaneously; therefore the net effect of mixed-litter decomposition could present different mixing effects in various processes [13]. Tanya found that biodiversity loss had consistent consequences for litter decomposition and the cycling of major elements over broad spatial scales [16]. However, few studies have investigated how the relative abundance and richness of aspen, birch and oak litter affect decomposition in temperate forests in northern China.

In addition, chemical and physical changes in the litter mixture can influence the decomposition rates through the decomposer community [17]. Therefore, an increase in the diversity and abundance of the decomposer community could result in greater mass loss because of an increase in microhabitats of the litter mixture $[12,17]$. Microorganisms transform more than $95 \%$ of the plant litter carbon in temperate coniferous forests $[18,19]$. Specially, fungi, compared with other microorganisms that exploit available resources, are more efficient and considered as the main decomposer by invading leaf litter and producing enzymes for degrading lignocellulose matrices through hyphae [20,21]. Many studies have shown that the substrates of leaf litter and their diversity in litter mixture could alter the abundance and structure of the universal fungal community [17,21,22]. In turn, as biocontrol agents, various communities of fungi have different biochemical capabilities to produce bioactive compounds, which could influence leaf litter decomposition [21,23,24]. Therefore, attention should be placed on investigating the relationship between fungal diversity and litter mixture decomposition to extend our knowledge of forest ecosystem functioning.

However, the traditional research methods used to investigate fungal communities have been limited to incomplete culture and induction of sporulation [25]. In contrast, molecular fingerprinting techniques, such as denaturing gradient gel electrophoresis (DGGE), are powerful for comparing fungal assemblages [26,27], which can rapidly detect all life stages of fungi without any sporulation or culturing $[21,28]$. Therefore, the molecular tools are more sensitive to variation between the abundance and spatial and temporal diversity of fungi. Although many studies have demonstrated the effects of leaf litter quality on decomposition [29,30], few have assessed the effect of litter quality on universal fungi, especially the effect of aspen (Populus davidiana Dode), birch (Betula platyphylla Sukaczev) and oak (Quercus mongolica Fischer ex Ledebour) litter on the universal fungal diversity in northern China using the PCR-DGGE method.

The objectives of this study were: (1) to investigate how the leaf litter species composition (aspen, birch and oak), relative abundance and richness affect the direction and magnitude of the litter mixture decomposition in temperate forests in northern China, and (2) to explore the relationships between litter mixture (species composition, relative abundance and richness) decomposition and the diversity of universal fungal assemblages in temperate forests in northern China.

\section{Materials and Methods}

\subsection{Study Site}

The study was conducted in the Liao River Source Nature Reserve (LRSNR, $41^{\circ} 01^{\prime}-41^{\circ} 21^{\prime} \mathrm{N}$, $118^{\circ} 22^{\prime}-118^{\circ} 37^{\prime}$ E), Pingquan County, Hebei Province, China. This nature reserve consists of an area of $3.355 \times 10^{4}$ ha, with elevations ranging from 625 to $1738 \mathrm{~m}$. The region is a transition between a 
temperate and cold-temperate zone, with a semi-humid and semi-arid continental monsoon mountain climate. The long-term mean annual precipitation is $550 \mathrm{~mm}$ and the mean annual evaporation is $1800 \mathrm{~mm}$. The mean annual temperature is $7.3{ }^{\circ} \mathrm{C}$ with monthly average temperatures ranging from $-10.8{ }^{\circ} \mathrm{C}$ (January) to $22.9{ }^{\circ} \mathrm{C}$ (July) [31]. Generally, the reserve has a brown and cinnamon type of soil, classified as a Eutriccambisol [32]. The typical vegetation of the mixed forests consists of deciduous broadleaved trees, i.e., aspen (Populus davidiana), birch (Betula spp.), oak (Quercus spp.) and shrubs (e.g., Prunus spp., Vitex negundo var. Hetertophylla and others).

\subsection{Experimental Design}

This work was conducted based on the Forestry Standards "Observation Methodology for Long-term Forest Ecosystem Research" of the People's Republic of China (LY/T 1952-2011) [33]. In late September 2012, when maximum litter fall occurred, we collected freshly senesced leaves of aspen, birch and oak from the forest floor. All litter was air dried immediately after collection at room temperature until a constant weight and stored for further use. To calculate the correction factor from air-dried weight to oven-dry weight, five sub-samples of the three litter species were dried to a constant weight at $75^{\circ} \mathrm{C}$. A detailed description of the chemical compositions of the three litter species is shown in Table 1. The chemical analyses used for the litter were performed according to the Forestry Standards of the People's Republic of China (LY/T 1952-2011) [33].

Table 1. Initial chemical properties of the three leaf litter species, i.e., aspen (Populus davidiana Dode), birch (Betula platyphylla Sukaczev) and oak (Quercus mongolica Fischer ex Ledebour) (mg/g).

\begin{tabular}{cccccccc}
\hline Species & $\mathbf{C}$ & $\mathbf{N}$ & $\mathbf{C} / \mathbf{N}$ & Lignin & Lignin/N & $\mathbf{P}$ & $\mathbf{K}$ \\
\hline aspen & $509.3 \pm 11.3 \mathrm{c}$ & $8.5 \pm 0.2 \mathrm{a}$ & $60.0 \pm 2.1 \mathrm{c}$ & $252.1 \pm 0.3 \mathrm{c}$ & $29.7 \pm 0.2 \mathrm{c}$ & $1.2 \pm 0.0 \mathrm{~b}$ & $3.5 \pm 0.1 \mathrm{~b}$ \\
\hline birch & $527.4 \pm 9.1 \mathrm{~b}$ & $7.5 \pm 0.3 \mathrm{~b}$ & $70.1 \pm 2.6 \mathrm{~b}$ & $263.6 \pm 0.3 \mathrm{~b}$ & $35.1 \pm 0.3 \mathrm{~b}$ & $1.2 \pm 0.0 \mathrm{a}$ & $2.4 \pm 0.1 \mathrm{c}$ \\
\hline oak & $551.7 \pm 10.5 \mathrm{a}$ & $6.9 \pm 0.2 \mathrm{c}$ & $80.3 \pm 2.2 \mathrm{a}$ & $290.0 \pm 0.3 \mathrm{a}$ & $42.2 \pm 0.3 \mathrm{a}$ & $0.9 \pm 0.0 \mathrm{c}$ & $5.5 \pm 0.1 \mathrm{a}$ \\
\hline
\end{tabular}

Data are means $\pm \mathrm{SE}(n=5)$. Different letters within a column indicate significantly different means $(p<0.05$, Tukey's test $)$.

The litterbag method, a widely used technique, was used for estimating the leaf litter decomposition rates during a 12-month period. Each litterbag $(20 \mathrm{~cm} \times 30 \mathrm{~cm})$ was constructed from polyethylene netting with a $1.0-\mathrm{mm} \times 1.5-\mathrm{mm}$ mesh size. The mesh size was intentionally chosen to impede the incorporation of mesofauna decomposers and to minimize the physical loss of small litter fragments [34].

Each bag was filled with $10 \mathrm{~g}$ of air-dried litter with a weight accuracy of $10^{-3} \mathrm{~g}$, labeled and sealed with rust-proof staples. We prepared the following eight types of litter bags: pure aspen litter (10A), pure birch litter (10B), pure oak litter (10O), 50\% aspen litter mixed with 50\% birch litter (5A:5B), $50 \%$ aspen litter mixed with 50\% oak (5A:5O), 50\% birch litter mixed with 50\% oak litter (5B:5O), $10 \%$ birch litter mixed with $80 \%$ aspen litter and 10\% oak litter (1B:8A:1O), 30\% birch litter mixed with $40 \%$ aspen litter and 30\% oak litter (3B:4A:30), where the two types of three species litter mixtures reflected the heterogeneity of the litter composition at the edge gaps and in the inner broadleaved mixed forests. Specifically, the proportions of each litter type in the litter mixtures 
multiplied by the gross dry weight $(10 \mathrm{~g})$ are the actual air-dried weight for each corresponding component litter species, which were fully mixed in each litter mixture. On 19 October 2012, 576 litter bags ( 8 litter types $\times 6$ litter bag replicates $\times 4$ harvests $\times 3$ replicate plots) were deployed on the floor of the three replicate plots, $50 \mathrm{~m}$ apart, in a similar landscape position, with similar topographic features, elevation and exposure (north facing) to ensure comparability between test results. The physical and chemical characteristics of the soil were as follows: bulk density $1.45 \pm 0.19 \mathrm{~g} \cdot \mathrm{cm}^{-3}, \mathrm{pH}$ $5.62 \pm 0.27$, organic matter $13.25 \pm 8.58 \mathrm{mg} \cdot \mathrm{g}^{-1}$, total $\mathrm{N} 0.93 \pm 0.72 \mathrm{mg} \cdot \mathrm{g}^{-1}$, total $\mathrm{P} 0.80 \pm$ $0.26 \mathrm{mg} \cdot \mathrm{g}^{-1}$, total $\mathrm{K} 4.55 \pm 0.12 \mathrm{mg} \cdot \mathrm{g}^{-1}$.

Five litterbags of each treatment were randomly retrieved and transported to the laboratory after 180, 240, 300 and 360 days of decomposition. The litter remaining in each bag was cleaned from extraneous matter, such as attached soil particles, in-growth plant materials and small animals, using tweezers and a brush. The contents of the three mixed-leaf litter samples were separated into their component species. Litter species identification was relatively easy, even after 360 days, due to the strong morphological and structural differences among the species. The separated litter samples were oven-dried at $75{ }^{\circ} \mathrm{C}$ for $72 \mathrm{~h}$ until a constant mass and then weighed to determine the remaining dry leaf mass. A total of 15 leaf litter types were obtained, consisting of pure birch, aspen and oak leaf-litter, as well as separated birch, aspen and oak leaf-litter, from each of the three two-species and two three-species litter mixtures. The remaining three litterbags were stored in a refrigerator at $4{ }^{\circ} \mathrm{C}$ and prepared for fungal DGGE (Denaturing Gradient Gel Electrophoresis) analyses after being completely mixed in one litterbag.

\subsection{DNA Extraction}

Fungal genomic DNA was extracted from the litter samples using the method improved by Griffiths et al. [35], in which $0.5 \mathrm{~g}$ litter samples were extracted with $0.5 \mathrm{~g}$ glass beads (diameter $0.1 \mathrm{~mm}), 900 \mu \mathrm{L}$ extraction buffer (100 mM Tris-HCl, $100 \mathrm{mM}$ EDTA, $1.5 \mathrm{M} \mathrm{NaCl}, \mathrm{pH} 8.0$ ), and beadbeated at $2000 \mathrm{rpm}$ for $30 \mathrm{~s}$ using a vortex. The separation and precipitation of the DNA followed the manufacturer's instructions for the fungal DNA extraction kit (Mo Bio Laboratories, Solana Beach, CA, USA). Specifically, the litter mixture used for DNA extraction was taken as one composite sample, without separation into components species.

\section{4. $P C R-D G G E$}

Fungal 18S rDNA was amplified with the universal primers NS1 (GTA GTC ATA TGC TFG TCT C) and GC-Fung (CGC CCG CCG CGC CCC GCG CCC GGC CCG CCG CCC CCG CCC CAT TCC CCG TTA CCC GTT G) [36]. All PCR amplifications were performed in $50 \mu \mathrm{L}$ reaction medium consisting of $5 \mu \mathrm{L} 10 \times$ buffer, $3.2 \mu \mathrm{L}$ dNTP $(2.5 \mathrm{mM}), 0.4 \mu \mathrm{L}$ rTaq $(5 \mathrm{U} / \mu \mathrm{L}), 1 \mu \mathrm{L}$ of each primer $(20 \mathrm{mM}), 100 \mathrm{ng}$ DNA template and sterilized Milli-Q water added to a volume of $50 \mu \mathrm{L}$. The PCR amplification program was conducted with a iCycler thermocycler PTC-220 (Bio-Rad, Hercules, CA, USA) using the following procedure: an initial denaturation cycle at $94{ }^{\circ} \mathrm{C}$ for $5 \mathrm{~min}$; 30 cycles of denaturation at $94{ }^{\circ} \mathrm{C}$ for $30 \mathrm{~s}$, annealing at $55^{\circ} \mathrm{C}$ for $30 \mathrm{~s}$ and extension at $72{ }^{\circ} \mathrm{C}$ for $30 \mathrm{~s}$; and a single final elongation at $72{ }^{\circ} \mathrm{C}$ for $10 \mathrm{~min}$. 
DGGE analysis was carried out using a D-Code mutation detection system (Bio-Rad, USA). For each sample, $40 \mu \mathrm{L}$ of PCR product and $20 \mu \mathrm{L}$ loading dye $(0.05 \%$ bromophenol blue, $0.05 \%$ xylene cyanol, $70 \%$ glycerol, sterilized water) were loaded into $8 \%$ acrylamide gel containing $20 \%-40 \%$ denaturing gradient in $7 \mathrm{~L}$ of $1 \times$ TAE-buffer (40 mM Tris/Acetate, $\mathrm{pH} 8 ; 1 \mathrm{mM}$ EDTA) at a constant $150 \mathrm{~V}, 60{ }^{\circ} \mathrm{C}$ for $8 \mathrm{~h}$ [37]. Then, the DGGE gels were visualized by silver staining, following Radojkovic and Kusic [38], and gel images were obtained using the Gel Imaging System (Bio-Rad Gel Doc 2000 Laboratories, Phoenix, AZ, USA). The DNA bands were identified and analyzed using Quantity One 4.6.2 software (Bio-Rad, Hercules, CA, USA).

Each detected band was identified as a ribotype, and the number of bands reflected the genotypic richness of each sample [39]. The relative abundance of each band $\left(p_{i}\right)$ was expressed as the pixel intensity of the band [40]. The Shannon-Wiener index of richness $(H)$ [41] was calculated with the following equation:

$$
\mathrm{H}=-\sum_{i=1}^{\mathrm{N}} p_{i} \ln p_{i}
$$

where $p_{i}=n_{i} / N, n_{i}$ is the pixel intensity of each band and $\mathrm{N}$ is the total intensity of the sample in a lane.

\subsection{Calculations}

The remaining litter mass $(\mathrm{RM})$ in each litterbag was calculated as the percentage of the initial litter dry weight $\left(X_{o}\right)$ by species at each sampling time $\left(X_{i}\right)$, using the formula as follows:

$$
\mathrm{RM}=X_{i} / X_{O} \times 100
$$

To quantify the dynamics of mass loss, a negative exponential decay function, developed by Olson [42] and further refined by Barlocher [43], was applied to the amount of litter over time, i.e., $W_{t}=W_{0} \times e^{-k t}$, where $\mathrm{W}_{t}$ is the remaining mass at time $t, \mathrm{~W}_{o}$ the initial mass of the litter, $k$ the rate of decomposition and $t$ the incubation time of the litterbags. The time required for $50 \%$ and $95 \%$ mass loss was calculated as $t_{50 \%}=-\ln 0.5 / k$ and $t_{95 \%}=-\ln 0.05 / k$, respectively [42].

The predicted relative remaining mass of each litter mixture was calculated based on the observed rates of decomposition in the monocultures of each component species and their initial ratios in the mixtures. This was calculated as follows [44]:

$$
\text { Predicted remaining mass }(\%)=\left[M_{1} /\left(M_{1}+M_{2}\right)\right] \times R_{1}+\left[M_{2} /\left(M_{1}+M_{2}\right)\right] \times R_{2}
$$

where $R$ is the remaining mass (\%) of the single litter species and $\mathrm{M}$ is the initial dry weight of each litter species in the mixture; the subscripts 1 and 2 represent the two leaf litter species in the mixture. The same formula theory was applied to the case of the mixture composed of the three litter species. The NAE (non-additive effect) of each litter mixture was calculated as the ratio [(predicted observed)/predicted] $\times 100 \%$ )] [45], which refers to remaining mass; negative NAE ratios suggest antagonistic mixture effects, while positive NAE ratios indicate synergistic mixture effects. At each sampling time, we calculated the expected mass loss of the litter mixtures on the basis of the measured rates of decomposition within the monocultures of each component species as well as their initial ratios in the mixtures. 


\subsection{Statistical Analysis}

In order to test whether non-additive (synergistic or antagonistic) litter mixture effects were significant, the differences between the predicted and observed decomposition mass loss of the mixtures were assessed by paired $t$-tests across the sample dates. One-way ANOVA was applied to examine the differences in species-specific initial litter quality. Two-way ANOVA was applied to (1) examine the differences in mass loss of the individual amounts in the litter decomposing as a single species compared with the individual amounts of litter in a mixture of species (we carried out separate analyses for each sampling time); and (2) test differences in mass loss between the five mixture treatments (the 5A:5B, 5A:5O, 5B:5O, 1B:8A:1O and 3B:4A:3O litter mixtures), with treatment and time as the major factors. For post hoc comparisons of mass loss, we used Tukey's multiple mean comparison test. Linear regression was performed to test the relationship between the accumulated mass loss and the number of fungal DGGE bands. All statistical analyses were carried out using SPSS version 13.0.1 statistical software (SPSS, Chicago, IL, USA), with the level of significance set at 0.05 in all cases.

\section{Results}

\subsection{Mass Loss}

Over 360 days of decomposition, the order of accumulated mass loss was $1 \mathrm{~B}: 8 \mathrm{~A}: 1 \mathrm{O}(54.5 \%)>$ $5 \mathrm{~A}: 5 \mathrm{~B}(54.4 \%)>3 \mathrm{~B}: 4 \mathrm{~A}: 3 \mathrm{O}(49.5 \%)>10 \mathrm{~A}(46.6 \%)>10 \mathrm{~B}(43.6 \%)>5 \mathrm{~A}: 5 \mathrm{O}(40.2 \%)>5 \mathrm{~B}: 5 \mathrm{O}$ $(39.5 \%)>100(28.0 \%$, Table 2$)$. With regard to the coefficient $k$ and the mass loss $\left(t_{50} \%, t_{95}\right)$ periods of litter decomposition, the orders of whose were similar to that of the mass loss (Table 3). The observed values of mass loss of the 1B:8A:1O, 3B:4A:3O and 5A:5B litter mixtures were significantly different from the predicted values calculated on the basis of the decomposition of monospecific litter $(p<0.01$, Table 2), producing significant synergistic effects on day 240 for $5 \mathrm{~A}: 5 \mathrm{~B}(t=-2.48$, $p=0.035), 1 \mathrm{~B}: 8 \mathrm{~A}: 1 \mathrm{O}(t=-2.15, p=0.031)$ and 3B:4A:3O $(t=-2.09, p=0.028)$, on day 300 for 5A:5B $(t=-2.54, p=0.032), 1 \mathrm{~B}: 8 \mathrm{~A}: 1 \mathrm{O}(t=-2.26, p=0.037)$ and 3B:4A:3O $(t=-2.33, p=0.026)$, as well as after 360 days for $5 \mathrm{~A}: 5 \mathrm{~B}(t=-2.38, p=0.041), 1 \mathrm{~B}: 8 \mathrm{~A}: 1 \mathrm{O}(t=-1.79, p=0.022)$ and 3B:4A:3O $(t=-1.93, p=0.034$, Figure 1$)$. However, the overall relative mixtures effect by day 180 did not differ significantly from 0 ( $p>0.05$, Figure 1$)$. Therefore, the synergistic effects increased over time but had declined by day 360 . In contrast, the $5 \mathrm{~A}: 5 \mathrm{O}$ and $5 \mathrm{~B}: 5 \mathrm{O}$ mixtures did not show a significant mixing effect on the mass remaining on all collection dates $(p>0.05)$ except for day 300 for 5A:5O $(t=-2.35, p=0.043)$ and 5B:5O $(t=-2.28, p=0.049$, Figure 1$)$, while the predicted values were marginally higher than the observed values.

By separating the litter remnants by species, we detected the effect of individual litter species in the mixtures on the remaining mass. In the $1 \mathrm{~B}: 8 \mathrm{~A}: 1 \mathrm{O}, 3 \mathrm{~B}: 4 \mathrm{~A}: 3 \mathrm{O}$ and $5 \mathrm{~A}: 5 \mathrm{~B}$ mixtures, the mass of aspen litter remaining was significantly lower than that of litter decomposing alone over the entire process $(p<0.05$, Table 2). The same conclusion applied to the birch and oak litter in these three litter mixtures. Moreover, in the 5A:5O and 5B:5O mixtures, the mass of aspen and birch remaining was apparently affected by the mixture since significant differences were found between the monospecific litter and the litter in the mixtures on all four sampling dates. Compared with monospecific oak litter, 
there were no significant differences in the oak mass remaining between the oak litter mixed with aspen and that mixed with birch $(p>0.05$, Table 2$)$.

Table 2. Mass loss of individual types of litter over 360 days for three tested leaf litter species and litter mixtures (means $\pm \mathrm{SE} ; n=3$ ).

\begin{tabular}{|c|c|c|c|c|c|c|}
\hline \multicolumn{7}{|c|}{ Mass Loss (\%) } \\
\hline & \multicolumn{3}{|c|}{ Individual litter } & \multicolumn{3}{|c|}{ Litter mixtures } \\
\hline & Aspen & Birch & Oak & Observed & Predicted & Difference \\
\hline $10 \mathrm{~A}$ & $46.6 \pm 1.5 \mathrm{~d}$ & & & $46.6 \pm 1.5 \mathrm{dC}$ & & \\
\hline $10 \mathrm{~B}$ & & $43.6 \pm 1.9 \mathrm{~d}$ & & $43.6 \pm 1.9 \mathrm{dD}$ & & \\
\hline $10 \mathrm{C}$ & & & $28.0 \pm 2.0 \mathrm{~b}$ & $28.0 \pm 2.0 \mathrm{bF}$ & & \\
\hline $5 \mathrm{~A}: 5 \mathrm{~B}$ & $55.8 \pm 1.8 \mathrm{~b}$ & $52.9 \pm 1.1 \mathrm{~b}$ & & $54.4 \pm 1.5 \mathrm{~A}$ & 45.1 & $9.3 b$ \\
\hline $5 \mathrm{~A}: 5 \mathrm{O}$ & $49.7 \pm 1.6 \mathrm{c}$ & & $30.5 \pm 1.9 b$ & $40.2 \pm 1.8 \mathrm{E}$ & 37.3 & $2.89 \mathrm{c}$ \\
\hline $5 \mathrm{~B}: 5 \mathrm{O}$ & & $48.5 \pm 1.2 \mathrm{c}$ & $30.5 \pm 1.4 \mathrm{~b}$ & $39.5 \pm 1.3 \mathrm{E}$ & 35.8 & $3.7 \mathrm{c}$ \\
\hline 1B:8A:1O & $56.9 \pm 1.3 b$ & $56.2 \pm 1.2 \mathrm{a}$ & $33.6 \pm 1.2 \mathrm{a}$ & $54.5 \pm 1.3 \mathrm{~A}$ & 44.4 & $10.1 \mathrm{a}$ \\
\hline $3 \mathrm{~B}: 4 \mathrm{~A}: 3 \mathrm{O}$ & $58.1 \pm 1.3 \mathrm{a}$ & $55.0 \pm 1.3 \mathrm{a}$ & $32.4 \pm 1.3 \mathrm{a}$ & $49.5 \pm 1.3 \mathrm{~B}$ & 40.1 & $9.4 \mathrm{~b}$ \\
\hline
\end{tabular}

Different letters indicate significant differences. Lowercase letters denote differences between monospecific litter and the litter in the mixtures, as well as the differences between the observed and predicted mass loss of the litter mixtures. Capital letters denote differences between the observed mass losses of the litter treatments. Two-way ANOVA for differences $(p<0.05)$ among individual litter types; $t$-tests for differences $(p<0.05)$ between observed and predicted values. Relative differences between predicted and measured mass loss of litter.

Table 3. Decomposition parameters $(a)$, coefficient $k$ and time (year) required for different levels of decomposition ( $t_{50 \%}$ and $t 95 \%$ mass loss) for the eight litter treatments (means $\pm \mathrm{SE} ; n=3$ ).

\begin{tabular}{cccccc}
\hline Litter Fraction & Parameter $\boldsymbol{a}$ & Coefficient $\boldsymbol{k}$ & $\boldsymbol{R}^{\mathbf{2}}$ & $\boldsymbol{T}_{\mathbf{5 0} \%}$ & $\boldsymbol{T}_{\mathbf{9 5} \%}$ \\
\hline 10A & $102.7 \pm 0.3 \mathrm{~b}$ & $0.6 \pm 0.0 \mathrm{c}$ & 0.98 & $1.1 \pm 0.1 \mathrm{~d}$ & $4.6 \pm 0.2 \mathrm{~d}$ \\
10B & $99.9 \pm 0.3 \mathrm{~d}$ & $0.5 \pm 0.0 \mathrm{~d}$ & 0.97 & $1.3 \pm 0.1 \mathrm{c}$ & $5.5 \pm 0.3 \mathrm{c}$ \\
10O & $104.2 \pm 0.3 \mathrm{a}$ & $0.4 \pm 0.0 \mathrm{f}$ & 0.98 & $1.8 \pm 0.1 \mathrm{a}$ & $7.8 \pm 0.3 \mathrm{a}$ \\
5A:5B & $98.3 \pm 0.3 \mathrm{e}$ & $0.7 \pm 0.0 \mathrm{~b}$ & 0.96 & $1.0 \pm 0.1 \mathrm{~d}$ & $4.4 \pm 0.2 \mathrm{~d}$ \\
5A:5O & $98.9 \pm 0.3 \mathrm{e}$ & $0.5 \pm 0.0 \mathrm{~d}$ & 0.97 & $1.3 \pm 0.1 \mathrm{c}$ & $5.6 \pm 0.2 \mathrm{c}$ \\
5B:5O & $101.7 \pm 0.3 \mathrm{c}$ & $0.5 \pm 0.0 \mathrm{e}$ & 0.99 & $1.4 \pm 0.1 \mathrm{~b}$ & $6.2 \pm 0.2 \mathrm{~b}$ \\
1B:8A:1O & $98.4 \pm 0.3 \mathrm{e}$ & $0.7 \pm 0.0 \mathrm{a}$ & 0.98 & $0.9 \pm 0.1 \mathrm{~d}$ & $4.1 \pm 0.3 \mathrm{~d}$ \\
3B:4A:3O & $98.4 \pm 0.3 \mathrm{e}$ & $0.7 \pm 0.0 \mathrm{c}$ & 0.97 & $1.1 \pm 0.1 \mathrm{~d}$ & $4.6 \pm 0.3 \mathrm{~d}$ \\
\hline
\end{tabular}

Values followed by different lowercase letters within a line indicate significant difference between means $(p<0.05)$. 


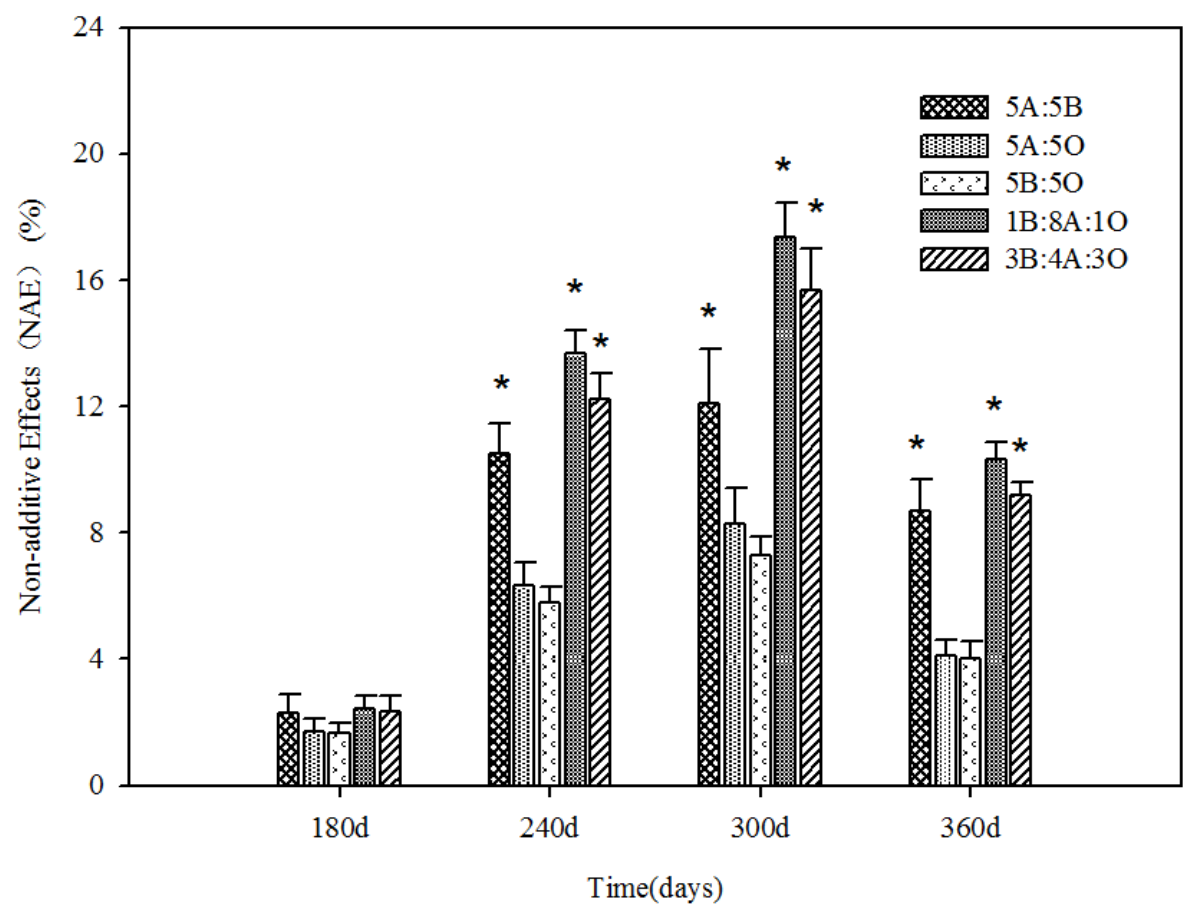

Figure 1. Non-additive effects (NAE) on mass remaining in all litter mixture treatments over time. $t$-tests were used to check whether NAE was significantly different from zero, indicated by *. Bars indicate SE $(n=3)$.

\subsection{Fungal Community Based on PCR-DGGE}

Fingerprinting analysis of the universal fungal community based on the PCR-DGGE technique indicated significant differences between the numbers of DGGE bands in all eight litter treatments during decomposition (Table 4). The initial numbers of DGGE bands were low, and increased to reach the maximum values at day 300, after which they decreased dramatically on day 360 , except for the 5A:5B and 5A:50 litter mixtures, for which the maximum DGGE bands occurred on day 240 (Table 4). The number of DGGE bands increased with an increase in the richness of the litter species. Specifically, the lowest number of DGGE bands was always detected in pure oak litter (10O), while the 5A:5B litter mixture had more DGGE bands than the 5A:5O and 5B:5O litter mixtures. Meanwhile, the number of DGGE bands in the 1B:8A:1O litter mixture was higher than that in the $3 \mathrm{~B}: 4 \mathrm{~A}: 3 \mathrm{O}$ litter mixture except on day 240. In addition, the diversity reflected by the Shannon-Weaver indices exhibited similar patterns as the variations in the DGGE bands. As can be seen in Figure 2, accumulated mass loss was significantly positively correlated with DGGE band number $\left(R^{2}=0.56\right.$, $p<0.001$ ), which explained $56.14 \%$ of the variance in mass loss for all litter treatments. 


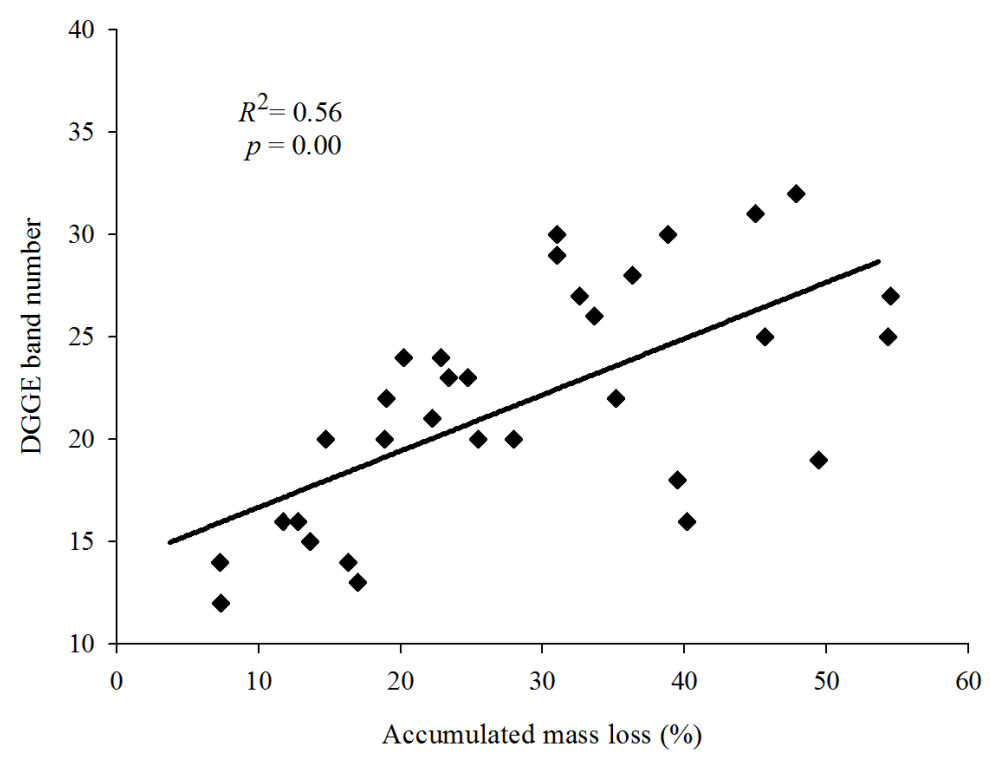

Figure 2. Linear relationships between the accumulated mass loss and the fungal DGGE band numbers.

Table 4. Shannon-Wiener index $(H)$, the richness of the DGGE bands $(S)$ and mass loss $(M)(\%)$ during the decomposition of the eight litter treatments.

\begin{tabular}{|c|c|c|c|c|c|}
\hline \multirow{2}{*}{ Treatments } & & \multicolumn{4}{|c|}{ Sampling Time (day) } \\
\hline & & 180 & 240 & 300 & 360 \\
\hline \multirow[t]{3}{*}{$10 \mathrm{~A}$} & $H$ & 2.5 & 3.0 & 3.5 & 2.6 \\
\hline & $S$ & 13 & 20 & 31 & 16 \\
\hline & $M$ & 18.3 & 26.7 & 38.9 & 46.6 \\
\hline \multirow[t]{3}{*}{ 10B } & $H$ & 2.5 & 3.1 & 3.3 & 2.5 \\
\hline & $S$ & 14 & 23 & 29 & 14 \\
\hline & $M$ & 16.5 & 25.5 & 38.4 & 45.6 \\
\hline \multirow[t]{3}{*}{100} & $H$ & 2.5 & 2.9 & 3.1 & 3.0 \\
\hline & $S$ & 12 & 20 & 24 & 20 \\
\hline & $M$ & 7.3 & 14.7 & 22.9 & 28.0 \\
\hline \multirow{3}{*}{$5 \mathrm{~A}: 5 \mathrm{~B}$} & $H$ & 3.0 & 3.3 & 3.2 & 3.2 \\
\hline & $S$ & 20 & 29 & 23 & 25 \\
\hline & $M$ & 21.6 & 40.8 & 45.3 & 54.4 \\
\hline \multirow[t]{3}{*}{$5 \mathrm{~A}: 5 \mathrm{O}$} & $H$ & 2.7 & 3.2 & 3.0 & 2.7 \\
\hline & $S$ & 15 & 23 & 20 & 16 \\
\hline & $M$ & 18.2 & 26.4 & 40.0 & 48.3 \\
\hline \multirow[t]{3}{*}{ 5B:5O } & $H$ & 2.7 & 3.0 & 3.2 & 2.9 \\
\hline & $S$ & 16 & 21 & 25 & 18 \\
\hline & $M$ & 13.9 & 22.0 & 32.5 & 39.5 \\
\hline \multirow[t]{3}{*}{ 1B:8A:1O } & $H$ & 3.2 & 3.2 & 3.4 & 3.1 \\
\hline & $S$ & 24 & 24 & 32 & 24 \\
\hline & $M$ & 23.6 & 42.5 & 47.6 & 54.5 \\
\hline \multirow[t]{3}{*}{$3 \mathrm{~B}: 4 \mathrm{~A}: 3 \mathrm{O}$} & $H$ & 3.0 & 3.4 & 3.4 & 2.9 \\
\hline & $S$ & 22 & 31 & 30 & 19 \\
\hline & $M$ & 20.4 & 39.5 & 43.5 & 52.6 \\
\hline
\end{tabular}




\section{Discussion}

Our data indicate that litter mixtures resulted in greater mass loss compared with pure litter (Table 3). This occurred because litter mixtures with similar physical structures result in the greatest synergistic effects on the mass loss of litter [46]. The presence of aspen litter increased the rate of decomposition of the birch litter in the mixtures, while birch litter in this mixture increased the rate of decomposition of the aspen litter in turn (Table 2). One potential mechanism for these interactions is resource complementarity among litter species [47], since higher-quality litter decomposes easily and then releases nutrient elements quickly, which could nourish microorganisms, increasing microbial biomass and enriching the diversity of decomposer communities of microbes and detritivores $[48,49]$. For instance, through leaching or fungal hyphae and microbes, $\mathrm{N}$ from high $\mathrm{N}$-containing litter could be transferred to low N-containing litter, accelerating the decomposition of lower quality litter [50]. The other potential mechanism for these interactions is the improvement of micro-environmental conditions and interactions across trophic levels, therefore stimulating the decomposition of leaf litter. For example, a number of studies have found that microorganisms obtain energy from water soluble-C, which results from litter decomposition, to grow and reproduce [51,52].

From a quantitative perspective, Ostrofsky [13] proposed that slowly decomposing oak litter would decompose faster in the presence of aspen or birch litter with higher $\mathrm{N}$ concentrations. Contrary to this hypothesis, we found that oak in the 5A:5O and 5B:5O litter mixtures was hardly affected by neighboring species, while aspen and birch in these mixtures decomposed faster than the monocultures (Table 2), resulting in an overall weaker positive non-additive effect in the mixtures (Figure 1). Meanwhile, PCR-DGGE analysis indicated that the number of universal fungal DGGE bands was lower in pure $10 \mathrm{O}$ litter than in the 5A:5O and 5B:5O litter mixtures (Table 4). This suggests that oak litter is characterized by strongly lignified leaf tissue so as to form a high structural stability, which could hamper further decomposition of leaf litter [53,54]. Similarly, Hoorens et al. found that rates of decay of slowly decomposing species are rarely accelerated in mixtures but such species could inhibit the decay of normally fast decomposing species [54]. By contrast, in our study, the rate of decomposition of aspen or birch in the $5 \mathrm{~A}: 5 \mathrm{O}$ or $5 \mathrm{~B}: 5 \mathrm{O}$ litter mixture was faster than that of monoculture aspen or birch leaf litter (Table 2). Alternatively, it could be also considered that the decomposition of lignin from relatively fast-decomposing litter could initially benefit from enzymes involved in lignin degradation in slow-decomposing litter [53,55].

In addition, the overall rate of decomposition did not increase with the increasing richness of the litter species, which was in accordance with the changes in the number of universal fungal DGGE bands. Meanwhile, in two types of 3-species litter mixtures, greater mass loss occurred in the 1B:8A:1O litter mixture compared with the 3B:4A:3O litter mixture (Table 2), which was positively correlated with the number of universal fungal DGGE bands (Table 4). Although the richness of the 5A:5B litter mixture was lower than that of the 3B:4A:3O litter mixture, the rate of decomposition of the $5 \mathrm{~A}: 5 \mathrm{~B}$ litter mixture was faster than that of the 3B:4A:3O litter mixture (Table 3). Similarly, the richness of the $5 \mathrm{~A}: 5 \mathrm{O}$ and $5 \mathrm{~B}: 5 \mathrm{O}$ litter mixtures was higher than the $10 \mathrm{~A}$ and $10 \mathrm{~B}$ litter, but the rate of decomposition of the $10 \mathrm{~A}$ and $10 \mathrm{~B}$ litter was faster than that of the $5 \mathrm{~A}: 5 \mathrm{O}$ and $5 \mathrm{~B}: 5 \mathrm{O}$ litter mixtures (Table 3). In summary, the presence and relative abundance of aspen determined the total rate of decomposition of the litter mixture and the fungal diversity, which is in accordance with Wu's finding 
that litter species identity and relative abundance are more important than richness in driving decomposition dynamics of litter mixtures [29]. The potential mechanism is that the increases in the litter substrate diversity and microhabitat complexity promote universal fungal diversity; therefore, the litter mixture is decomposed more efficiently than monospecific litter [56]. However, the rate of decomposition of the litter mixture still depends on the total quality of the litter mixture, e.g., the aspen litter, with a relatively high $\mathrm{N}$ content but low $\mathrm{C} / \mathrm{N}$ and lignin/ $\mathrm{N}$ (Table 1), can nourish a greater number of microbes, which enhance the overall decomposition rate in turn [29].

Our results indicate the positive non-additive effect of litter mixture changes over time (Figure 1). Changes in NAE over time were determined by litter quality, decomposer community and the temporal variations in the microclimate during the decomposition process [11,57]. At the end of the study in autumn, leaching and decomposition of labile compounds in the litter mixture decreased so that the activity of the microorganisms weakened with a reduction in temperature. In addition, microorganism biomass and biological diversity decreased as the litter degraded with ongoing incubation (Table 4), which contributed to the decrease in the magnitude of NAEs (Figure 1). Lecerf et al. found that the magnitude of NAEs and the relative balance of positive and negative effects of the same litter mixture would change over time [58]. Changes in NAE as a function of time may have a substantial impact on biogeochemical cycling over the long term [29]. These studies showed that this effect could be attributed to the complex process of litter decomposition, in which the sequential presence and accumulation of various chemical compounds in litter mixtures may trigger effects that either facilitate or inhibit decomposers at different temporal scales.

\section{Conclusions}

In summary, the mass losses of the litter mixtures were considerably greater than those of individual litter, which were significantly positively correlated with the number of universal fungal DGGE bands. Specifically, the presence and high relative abundance of aspen and birch litter stimulated the decomposition of the litter mixture more efficiently than oak litter. Moreover, the magnitude of the non-additive effects changed over time. The $5 \mathrm{~A}: 5 \mathrm{~B}, 1 \mathrm{~B}: 8 \mathrm{~A}: 1 \mathrm{O}$ and $3 \mathrm{~B}: 4 \mathrm{~A}: 3 \mathrm{O}$ litter mixtures had a synergistic effect on litter mixture, while the 5A:5O and 5B:5O litter mixtures had a nearly neutral effect on litter mixture. Therefore, our assessment of the effect of leaf litter diversity on decomposition and associated fungal assemblages, revealed that species composition and relative abundance were more important than richness in driving the magnitude of non-additive effects of decomposition of litter mixture.

\section{Acknowledgments}

This paper was supported by the CFERN \& GENE (forest ecological service function distributed localization observation and model simulation) Award Funds on Ecological paper and the National Forestry Public Welfare Professional Scientific Research project (no. 201204101). The authors thank all those who provided helpful suggestions and critical comments on this manuscript, as well as anonymous reviewers. We gratefully acknowledge the support from the Pingquan forestry bureau and Liao River Source Forest Ecological Research Station for their support with the field work, especially Weimin Hu, Shuwen Han. 


\section{Author Contributions}

Jing Gao conceived and designed the experiments. Hairong Han and Fengfeng Kang are the supervisors of Jing Gao. They supervised all the work, from the thesis proposal to implementation. Jing Gao, Tianyu Li, Xiaoshuai Song, Weihong Zhao, Xiaowen Yu and Jinlong Zhao contributed to field work. Jing Gao and Tianyu Li conducted all laboratory work. Jing Gao carried out the statistical analyses and wrote the manuscript.

\section{Conflicts of Interest}

The authors declare no conflict of interest.

\section{References}

1. Fuqiang, S.; Xiaoxu, F.; Ruiqing, S. Review of mixed forest litter decomposition researches. Acta Ecol. Sin. 2010, 30, 221-225.

2. Aerts, R. Climate, leaf litter chemistry and leaf litter decomposition in terrestrial ecosystem; a triangular relationship. Oikos 1997, 79, 439-449.

3. Cornwell, W.K.; Cornelissen, J.H.C.; Amatangelo, K.; Dorrepaal, E.; Eviner, V.T.; Godoy, O.; Hobbie, S.E.; Hoorens, B.; Kurokaw, H.; Perez Harguindeguy, H.; et al. Plant species traits are the predominant control on litter decomposition rates within biomes worldwide. Ecol. Lett. 2008, 11, 1065-1071.

4. Aponte, C.; Garcia, L.V.; Maranon, T. Tree Species Effect on Litter Decomposition and Nutrient Release in Mediterranean Oak Forests Changes over Time. Ecosystems 2012, 15, 1204-1218.

5. Cleveland, C.C.; Reed, S.C.; Keller, A.B.; Nemergut, D.R.; O’Neill, S.P.; Ostertag, R.; Vitousek, P.M. Litter quality versus soil microbial community controls over decomposition: A quantitative analysis. Oecologia 2014, 174, 283-294.

6. Taylor, B.R.; Parkinson, D.; Parsons, W.F.J. Nitrogen and lignin content as predictors of litter decay rates: A microcosm test. Ecology 1989, 70, 97-104.

7. Polyakova, O.; Billor, N. Impact of deciduous tree species on litterfall quality, decomposition rates and nutrient circulation in pine stands. For. Ecol. Manag. 2007, 253, 11-18.

8. Hobbie, S.E.; Reich, P.B.; Oleksyn, J.; Ogdahl, M.; Zytkowiak, R.; Hale, C.; Karolewski, P. Tree species effects on decomposition and forest floor dynamics in a common garden. Ecology 2006, 87, 2288-2297.

9. Berg, B.; Steffen, K.; McClaugherty, C. Litter decomposition rate is dependent on litter Mn concentrations. Biogeochemistry 2007, 82, 29-39.

10. Dorrepaal, E.; Cornelissen, J.H.C.; Aerts, R.; Wallén, B.; van Logtestijn, R.S.P. Are growth forms consistent predictors of leaf litter quality and decomposability across peatlands along a latitudinal gradient? J. Ecol. 2005, 93, 817-828.

11. De Marco, A.; Meola, A.; Maisto, G.; Giordano, M.; De Santo, A.V. Non-additive effects of litter mixtures on decomposition of leaf litters in a Mediterranean maquis. Plant Soil 2011, 344, 305-317. 
12. Gartner, T.B.; Cardon, Z.G. Decomposition dynamics in mixed-species leaf litter a review. Oikos 2004, 104, 230-246.

13. Ostrofsky, M.L. A comment on the use of exponential decay models to test non-additive processing hypotheses in multispecies mixtures of litter. J. N. Am. Benthol. Soc. 2007, 26, $23-27$.

14. McTiernan, K.B.; Ineson, P.; Coward, P.A. Respiration and nutrient release from tree leaf litter mixtures. Oikos 1997, 78, 527-538.

15. Hättenschwiler, S.; Vitousek, P.M. The role of polyphenols in terrestrial ecosystem nutrient cycling. Trends Ecol. Evol. 2000, 15, 238-243.

16. Handa, T.; Aerts, R.; Berendse, F.; Berg, M.P.; Bruger, A,; Butenschoen, O.; Chauvet, E.; Gessner, M.O.O.; Jabiol, J.; Makkonen, M.; Mckie, B.G.; Malmqrist, B.; Peeters, E.T.H.M.; Scheu, S.; Schmd, B.; Ruijven, J.; Vos, V.C.A.; Hättenschwiler, S. Consequences of biodiversity loss for litter decomposition across biomes. Nature 2014, 509, 218-221.

17. Fuzhong, W.; Changhui, P.; Wanqin, Y.; Jian, Z.; Yu, H.; Tao, M. Admixture of alder (Alnus formosana) litter can improve the decomposition of eucalyptus (Eucalyptus grandis) litter. Soil Biol. Biochem. 2014, 73, 115-121.

18. Rasche, F.; Cadisch, G. The molecular microbial perspective of organic matter turnover and nutrient cycling in tropical agroecosystems-What do we know? Biol. Fertil. Soils 2013, 49, 251-262.

19. Berg, B.; Laskowski, R.; Caswell, H. Litter decomposition: A guide to carbon and nutrient turnover. Adv. Ecol. Res. 2006, 38, 20-182.

20. Moller, J.; Miller, M.; Kjoller, A. Fungal-bacterial interaction on beech leaves: Influence on decomposition and dissolved organic carbon quality. Soil Biol. Biochem. 1999, 31, 367-374.

21. Xiaoxu, F.; Fuqiang, S. Dynamics of fungal diversity in different phases of Pinus litter degradation revealed through denaturing gradient gel electrophoresis (DGGE) coupled with morphological examination. Afr. J. Microbiol. Res. 2011, 5, 5674-5681.

22. Orwin, K.H.; Wardle, D.A.; Greenfield, L.G. Ecological consequences of carbon substrate identity and diversity in a laboratory study. Ecology 2006, 87, 580-593.

23. Aly, A.H.; Debbab, A.; Kjer, J.; Proksch, P. Fungal endophytes from higher plants: A prolific source of phytochemicals and other bioactive natural products. Fungal Divers. 2010, 41, 1-16.

24. Xu, J.; Ebada, S.S.; Proksch, P. Pestalotiopsis a highly creative genus: Chemistry and bioactivity of secondary metabolites. Fungal Divers. 2010, 44, 15-31.

25. Giordano, L.; Gonthier, P.; Varese, G.C.; Miserere, L.; Nicolotti, G. Mycobiota inhabiting sapwood of healthy and declining Scots pine (Pinus sylvestris L.) trees in the Alps. Fungal Divers. 2009, 38, 69-83.

26. Hossain, M.Z.; Sugiyama, S. Influences of plant litter diversity on decomposition, nutrient mineralization and soil microbial community structure. Jpn. Soc. Grassl. Sci. 2010, 57, 72-80.

27. Anzhou, M.; Xuliang, Z.; Junmei, W.; Mengmeng, C.; Di, L.; Chunzhao, L.; Guoqiang, Z. Ascomycota Members Dominate Fungal Communities during Straw Residue Decomposition in Arable Soil. PLoS ONE 2013, 8, e66146.

28. Ming, N.; Han, M.; Ke, L.; Jiarong, W.; Zhexue, Q.; Changming, F.; Jiakuan, C.; Bo, L. Comparison of bacterial and fungal communities between natural and planted pine forests in subtropical China. Current Microbiology 2012, 64, 34-42. 
29. Dongdong, W.; Tingting, L.; Shiqiang, W. Time and litter species composition affect litter-mixing effects on decomposition rates. Plant Soil 2013, 371, 355-366.

30. Daijiang, L.; Shaolin, P.; Baoming, C. The effects of leaf litter evenness on decomposition depend on which plant functional group is dominant. Plant Soil 2013, 365, 255-266.

31. Jinlong, Z.; Fengfeng, K.; Luoxin, W.; Xiaowen, Y.; Weihong, Z.; Xiaoshuai, S.; Yanlei, Z.; Feng, C.; Yu, S.; Tengfei, H.; et al. Patterns of Biomass and Carbon Distribution across a Chronosequence of Chinese Pine (Pinus tabulaeformis) Forests. PLoS ONE 2014, 9, e94966.

32. World Soil Resources Report No. 103. In World Reference Base for Soil Resources; FAO, ISRIC, ISSS: Rome, Italy, 2006.

33. Forestry Standards "Observation Methodology for Long-Term Forest Ecosystem Research" of People's Republic of China (LY/T 1952-2011); FERN: Beijing, China, 2011.

34. Karberg, N.J.; Scott, N.A.; Giardina, C.P. Methods for estimating litter decomposition. In Field Measurements for Forest Carbon Monitoring; Hoover, C.M., Ed.; Springer: New York, NY, USA, 2008; pp. 103-110.

35. Griffiths, R.I.; Whiteley, A.S.; O’Donnell, A.G.; Bailey, M.J. Rapid method for coextraction of DNA and RNA from natural environments for analysis of ribosomal DNA- and rRNA-Based microbial community composition. Appl. Environ. Microbiol. 2000, 66, 5488-5491.

36. White, T.J.; Bruns, T.; Lee, S.; Taylor, J. Amplification and direct sequencing of fungal ribosomal RNA genes for phylogenetics. In PCR Protocols-A Guide to Methods and Applications; Michael, A.I., David, H.G., John, J.S., Thomas J.W., Eds.; Academic Press: San Diego, CA, USA, 1990; pp. 315-322.

37. Muyzer, G.; Smalla, K. Application of denaturing gradient gel electrophoresis (DGGE) and temperature gradient gel electrophoresis (TGGE) in microbial ecology. Antonie Leeuwenhoek 1998, 73, 127-141.

38. Radojkovic, D.; Kusic, J. Silver staining of denaturing gradient gel electro-phoresis gels. Clin. Chem. 2000, 46, 883-884.

39. Bell, T.; Ager, D.; Song, J.I.; Newman, J.A.; Thompson, I.P.; Lilley, A.K.; van der Gast, C.J. Larger islands house more bacterial taxa. Science 2005, 308, 1884.

40. Reche, I.; Pulido-Villena, E.; Morales-Baquero, R.; Casamayor, E.O. Does ecosystem size determine aquatic bacterial richness? Ecology 2005, 86, 1715-1722.

41. Trevors, J.T.; Kevan, P.G.; Tam, L. Microbial diversity across a Canadian sub-Arctic, isostatically rebounding, soil transect. Polar Sci. 2010, 4, 81-91.

42. Olson, J.S. Energy storage and balance of producers and decomposers in ecological systems. Ecology 1963, 44, 322-331.

43. Baerlocher, F. Leaf mass loss estimated by litter bag technique. In Methods to Study Litter Decomposition-A Practical Guide; Graca, M.A.S., Barlocher, F., Gessner, M.O., Eds.; Springer-Verlag New York: Dordrecht, Netherlands, 2007; pp. 37-42.

44. Hoorens, B.; Stroetenga, M.; Aerts, R. Litter mixture interactions at the level of plant functional types are additive. Ecosystems 2010, 13, 90-98.

45. Wardle, D.A.; Bonner, K.I.; Nicholson, K.S. Biodiversity and plant litter: Experimental evidence which does not support the view that enhanced species richness improves ecosystem function. Oikos 1997, 79, 247-258. 
46. Chapman, S.K.; Koch, G.W. What type of diversity yields synergy during mixed litter decomposition in a natural forest ecosystem. Plant Soil 2007, 299, 153-162.

47. Schimel, J.P.; Hättenschwiler, S. Nitrogen transfer between decomposing leaves of different N status. Soil Biol. Biochem. 2007, 39, 1428-1436.

48. Gessner, M.O.; Swan, C.M.; Dang, C.K.; Mckie, B.G.; Bardgett, R.D.; Wall, D.H.; Hättenschwiler, S. Diversity meets decomposition. Trends Ecol. Evol. 2010, 25, 372-380.

49. Swan, C.M.; Palmer, M.A. Preferential feeding by an aquatic consumer mediates non-additive decomposition of species leaf litter. Oecologia 2006, 149, 107-114.

50. Qingkui, W.; Silong, W.; Yu, H. Leaf litter decomposition in the pure and mixed plantations of Cunninghamia lanceolata and Michelia macclurei in subtropical China. Biol. Fertil. Soil 2009, 45, 371-377.

51. Kalbitz, K.; Solinger, S.; Park, J.H.; Michalzik, B.; Matzner, E. Controls on the dynamics of dissolved organic matter in soils: A review. Soil Sci. 2000, 165, 277-304.

52. Neff, J.C.; Asner, G.P. Dissolved Organic Carbon in Terrestrial Ecosystems: Synthesis and a Model. Ecosystems 2001, 4, 29-48.

53. Marlin, P.S.; Arredondo-Moreno, J.T.; Elisabeth, H.S. Early stage of single and mixed leaf-litter decomposition in semiarid forest pine-oak: The role of rainfall and microsite. Biogeochemistry 2012, 108, 245-258.

54. Hoorens, B.; Coomes, D.; Aerts, R. Neighbour identity hardly affects litter-mixture effects on decomposition rates of New Zealand forest species. Oecologia 2009, 162, 479-489.

55. Pauly, M.; Keegstra, K. Cell-wall carbohydrates and their modification as a resource for biofuels. Plant J. 2008, 54, 559-568.

56. Wardle, D.A.; Yeates, G.W.; Barker, G.M.; Bonner, K.I. The influence of plant litter diversity on decomposer abundance and diversity. Soil Biol. Biochem. 2006, 38, 1052-1062.

57. Hector, A.; Beale, A.J.; Minns, A.; Otway, S.J.; Lawton, J.H. Consequences of the reduction of plant diversity for litter decomposition: Effects through litter quality and microenvironment. Oikos 2000, 90, 357-371.

58. Lecerf, A.; Marie, G.; Kominoski, J.S.; LeRoy, C.J.; Bernadet, C.; Swan, C.M. Incubation time, functional litter diversity, and habitat characteristics predict litter-mixing effects on decomposition. Ecology 2011, 92, 160-169.

(C) 2015 by the authors; licensee MDPI, Basel, Switzerland. This article is an open access article distributed under the terms and conditions of the Creative Commons Attribution license (http://creativecommons.org/licenses/by/4.0/). 